\title{
Exploring the Dynamic Changes between Mothers and Teenagers through Family and School Programs
}

Hasny@Yanti Zainal, Samsilah Roslan, Norlizah Che Hassan, Noorlila Ahmad

To Link this Article: http://dx.doi.org/10.6007/IJARBSS/v11-i2/8737

DOI:10.6007/IJARBSS/v11-i2/8737

Received: 03 January 2021, Revised: 27 January 2021, Accepted: 10 February 2021

Published Online: 17 February 2021

In-Text Citation: (Zainal et al., 2021)

To Cite this Article: Zainal, H., Roslan, S., Hassan, N. C., \& Ahmad, N. (2021). Exploring the Dynamic Changes between Mothers and Teenagers through Family and School Programs. International Journal of Academic Research in Business and Social Sciences, 11(2), 279-293.

\section{Copyright: @ 2021 The Author(s)}

Published by Human Resource Management Academic Research Society (www.hrmars.com)

This article is published under the Creative Commons Attribution (CC BY 4.0) license. Anyone may reproduce, distribute, translate and create derivative works of this article (for both commercial and non-commercial purposes), subject to full attribution to the original publication and authors. The full terms of this license may be seen at: http://creativecommons.org/licences/by/4.0/legalcode

Vol. 11, No. 2, 2021, Pg. 279 - 293

Full Terms \& Conditions of access and use can be found at http://hrmars.com/index.php/pages/detail/publication-ethics 


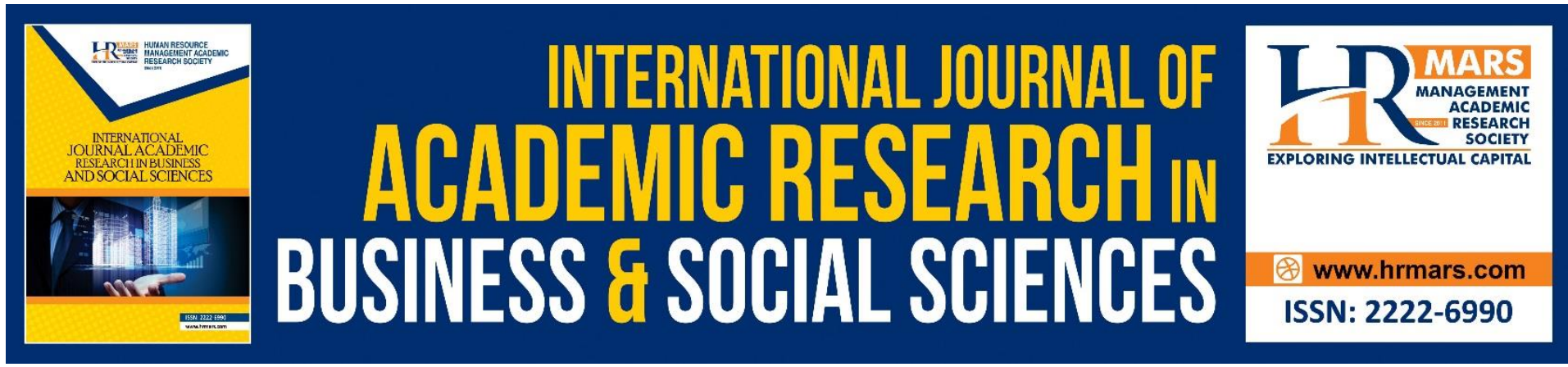

\title{
Exploring the Dynamic Changes between Mothers and Teenagers through Family and School Programs
}

\author{
Hasny@Yanti Zainal' ${ }^{1}$, Samsilah Roslan ${ }^{1}$, Norlizah Che \\ Hassan $^{1}$, Noorlila Ahmad ${ }^{2}$ \\ ${ }^{1}$ Faculty of Educational Studies, Universiti Putra Malaysia, Serdang, Selangor, Malaysia, \\ 43400, ${ }^{2}$ Kulliyyah of Education, International Islamic University Malaysia, Gombak, \\ Selangor, Malaysia, 53100 \\ Email: samsilah@upm.edu.my
}

\begin{abstract}
This study presents the effects of Family and School Together (FAST) Programme that was executed for the first time as part of a research study under Universiti Putra Malaysia (UPM) and The National Population and Family Development Board (NPFDB) of Ministry of Women, Family and Community Development. The purpose of this study is to explore the dynamic relationship between mothers-children and the community, which includes school involvement in overcoming disciplinary issues. This study employed a qualitative case study design using purposive sampling at an eight-week enrolled programme. Data was collected using in-depth interviews, direct observation and document analysis, triangulated using a multi-source data approach and were analysed using the NVivo 8 software. The research findings indicated that collaborative family and school programs affect the relationship between mothers and teenagers. The FAST program through peers' activities and one to one activity, has shown to increase the element of communication skills and mothers' parenting practices.
\end{abstract}

Keywords: Program Family and School Together (FAST), Mother, Teenager, Discipline.

\section{Introduction}

The World Health Organization (WHO) defines teenagers who are between the age of $12-19$ and in the developmental stage of their biological, physical, psychological, and moral faculties as being in the transitional period from childhood to adulthood. The disparity between the two periods generally influences the physical, mental, and emotional changes that occur during the formation of identity among teenagers, which is often misconstrued. This often brings into effect disciplinary misconduct for lack of experience, poor judgment, and environmental influences from families and peers.

Past research has asserted that the functionality of a family can positively or negatively influence the life of an individual (Yousef, 2017). Apart from that, communication is also seen as relevant to express needs, wants, care, and love which form the foundation of family life 
(Manap et al., 2013). Past research summaries have also stressed the role of parental responsibility in equipping children with religious, beliefs and moral values that could serve as a basis for harmony in a family institution (Yahaya \& Yatim, 2018). Yet, conflicts that arise from communication failure, divorce, abuse, substance abuse, absence of a loving environment, etc. are known to occur in a family (Sarnon et al., 2018). Such shortcomings in familial matters can lead to disciplinary problems among schooling teenagers that often begin with truancy issues as a result of peer pressure that plays a stronger part in their lives compared to families (Amin et al., 2019). The role and responsibility of parents as role models are crucial to creating an environment of positive relationship and motivational drive in the personality development and self-development of teenagers (Ishak et al., 2009).

Additionally, there must be an agreement in family, school, social, and community space to empower a dynamic relationship that can reduce problems of discipline and misconduct among children. In the FAST program, Mc Donald and Frey (1999) focuses on elements of family, school, and community that are known to be capable of developing children's potential. Early Functionalism theory (Durkheim 1858 - 1917) bridges the function of schools and their relationship with society as a basis of social rules that are co-dependent. Hidayah and Suhaizal (2018) state that the FAST program requires the collaboration of various parties for maximum impact for affected teenagers, families, and communities. As such, the relevance of this theory stresses the aspects of choosing and training resources to contribute towards the relationship and dynamic development of the society.

Bandura (1977) stresses environmental aspects through reinforcement and observational learning. The FAST program emphasizes observational training activities as a means of preventing aggressive behavior and emulating positive role models during the process of intervention. Among the positive factor models that influence behaviors in the FAST program are the stimulus characteristics model, types of behaviors that should be emulated, and recurring impacts of behavior and motivation throughout the program.

This study is conducted to explore the effectiveness of Family and school Together (FAST) as an intervention program that is implemented with the collaborative efforts of schools and families. In particular, the study aims to identify the strengths and weaknesses of FAST as an intervention program in the Malaysian context.

\section{Relationship between parents, school, and community}

\section{a. $\quad$ Parents and Children}

Roles and responsibilities are crucial in determining the nature of the relationship between parents and children. Parental efficacy, the functionality of families, and the psychological well-being of children are determining factors of the success of a family institution (Desa et al., 2015). The dysfunctionality of a family is closely linked to negative qualities such as anxiety and social and behavioral problems (Othman et al., 2019). Focus on family functionality is the key ingredient of success in relationships which can be achieved through interactive communication, quality leisure time together, openness, acceptance, and involvement between family members where the development of children's lives are concerned (Desa et al., 2015).

Parents need to be actively involved in monitoring and focusing on their children's activities (Awal et al., 2014). Such a role and responsibility must be taken seriously because the role of 
the familial institution is the backbone of personality development in the lives of teenagers (Najwa et al., 2019). Families influence the attitude, speech, and personality of an individual through parenting methods and by acting as role models for the children. Therefore, familybased intervention programs emphasize greatly on parental roles and responsibilities through planned activities that help build dynamic communication with the children.

Past studies have found that communication patterns in families greatly influence personality development and issues of misconduct among teenagers (Bakar, 2015). Patton and Giffin (1977) earlier attested that the formation of identity, enhanced self-esteem, and one's ability to face the realities of life depend on the quality of interpersonal communication. Parents need to develop positive communication practices amidst their children to ensure that there exists satisfaction towards the overall quality of life which includes non-verbal communication as a means of emotional support (Barnes \& Olson, 1985; Trees, 1999).

Children's filial relationship with their family is largely dependent on the parenting style that they are exposed to. Authoritarian parenting often results in an educational style that is firm and strict. The impact of such a style results in children secluding themselves from society, acting aggressively, and possessing high expectations of themselves and others (Bezrukova \& Samoylova, 2015). According to past research, such a parenting style is widely practiced in families of low socioeconomic standing to inculcate control values and strict teaching which pushes for the punishment of children (Talib et al., 2017). Additionally, failure in monitoring children's activities is a form of permissive parenting. Authoritative parenting can produce teenagers who are more positively inclined through methods of encouragement, motivation, concern and being driven by the children's success (Nurshahizan, 2014). Democratic style of parenting enables children to be more energetic, inquisitive, and become keen to explore (Baumrind, 1989). Teenagers who are seeking their self-identity greatly require support, encouragement, and love which can be achieved through better communication, attitude, role, and responsibility of parents in designing harmony and pillars of the familial institution (Hashim \& Nin, 2011).

\section{b. $\quad$ Filial relationship between mother and children}

Numerous studies have involved functions of both parents but the impact of single-mother families on the growth and development of children must also be taken into account. A polemic single mother scenario is not new to our society. The number of single mothers in Malaysia is increasing from year to year and is becoming a challenge where income-earning, managing, and educating children, and opinions of the society are concerned (Akhtar et al., 2017). Such challenges result in stress and emotional disturbances in aspects of selfmanagement because of conflicts related to self and family (Becker \& Luthar, 2002).

Single mothers need to find a way to manage their emotions without negatively affecting their children. Zulkefli and Mustapha (2016) found that teenagers are prone to act negatively if parents go through the process of divorce. As a result, children would find it difficult to discuss their problems or emotional expressions with both their parents. Male children are more prone to communicate with their peers (Zulkefli \& Mustapha, 2016). Mothers however are more comfortable in discussing their feelings and emotions with their female children as compared to male children (Brody, 1985). And so, children of parents who are filially distant from them are prone to negative behavior, creating problems at school and failing to 
effectively regularise their emotions. In such cases, family-centered intervention programs between mothers and teenagers such as FAST can encourage emotions, interactive communications, and the application of noble values.

\section{c. Collaborations between parents, schools, and communities}

According to the structural-functionalism perspective, the family is the most important pillar of society and serves as the first and foremost foundation in the process of socialization and learning. Yet, in the era of modern society development, schools through their formal educational systems have replaced the function of socialization (Abdullah et al., 2015). Decades ago, researchers stressed that schools function as the lifeline of community, social control centers, and to integrate community living (Garstin, 1948). Numerous studies coherently established that schools serve as formal educational organizations as well as social institutions that aim to enhance social lives (Sanders \& Harvey, 2002). The diverse roles of schools can also be seen in successful collaborations between schools and societies which demonstrate evidence of commitment, leadership, consistent sharing, return on investments, frequent communication, and programs of higher quality than quantity (Gross, 2015). By and large, the consensus between families, schools, and communities is known to contribute greatly to students' self-development and academic success (Sheldon, 2016).

Numerous collaborative programs target The Thurston Family Project (TTFP) family intervention to promote teamwork between schools and families through external activities as a means of controlling problematic behavior (Clarke et al., 2015). The Social Skills Group Intervention Adolescent program, for instance, is used to increase social skills (Harrell et al., 2009) while the Strengthening Families program encourages the involvement of families in managing social behaviors and relationships of teenagers. Foxcroft et al. (2017) found that as a result of such programs, parents were able to exhibit enhanced skills in overcoming problems and increasing the functionality of the family which resulted in positive relationships with teenagers. Additionally, the FAST program also stresses characteristics similar to the Strengthening Families program which emphasizes effective interactive communication and inculcation of noble values in relations between families, schools, and communities.

\section{Family and School Together Program (FAST)}

This program was developed by McDonald and Frey (1999) to help build better relations through a family-based grouping approach and therapy to contain teenagers' mischief issues. FAST is a learning program that is based on planned experiences intended to increase social models, build relationships, and at the same time, reduce family pressures and heighten the attentiveness of children (Kratochwill et al., 2009). FAST, therefore, is formulated to increase parental control and is targeted to involve parents who earn low incomes, are pressured, and secluded.

The success of the implementation of the FAST intervention model is based on design planning of activities, resource capacity, and the ability of employees to expand on the reach of interventions (Grayson, 2013). Abdullah et al. (2015) stated that the FAST program showed an increase in academic competency and achievement reinforcement of positive behavior, social skills, and attention span among students. This incidentally helps reduce behavioral 
problems such as anxiety and depression that could impact social interactions either at home or schools and the same time, impact academic achievement.

The success of the FAST program is measured by its process of implementation which includes the development of planned activities and collaborative networks between various parties. When discussing changes that occur between families and children, Berger et al. (2016) list the effectiveness of the FAST program through activities at family tables, activities with family members, peers, and one-to-one activities. One-to-one activities involve the need for role models to monitor the growth of teenagers from the ages of 12 till 17 since it is during these years that they are most easily influenced by their peers (Taylor, 2015). And so, the FAST program can help teenagers gauge and improve their behaviors with the guidance of a positive role model for positive affirmation. Besides that, the element of one-to-one parenting which involves the connection between one mother with another enhances the role of mothers in creating a close-knit relationship with children and reducing negative behaviors of children at home (Valentine et al., 2019). Activities of the FAST program assimilates moral values from the perspectives of family unity, filial values between mother and child, sense of responsibility, love, and respect. This fosters integration in the family institution that involves strengthening the relationship between the mother and child through discussion, involvement and supervision (Voydanoff et al., 1988).

\section{Material and Methods}

Research Design

The first purpose of this case study was to understand the mothers-teenagers' relationship. Thus, a qualitative case study methodology was employed to explore the mother-teenager relationship based on disciplinary issues mediated through the FAST program model. According to Baxter and Jack (2008), a qualitative case study is a research technique that aims to examine the phenomenon within a specific context through a variety of data sources and undertakes an exploration through a variety of lenses to uncover different aspects of the phenomenon. It becomes a valuable method for health science research to develop theory, evaluate programs, and develop interventions. As stated by Patton (2002), case studies offer an opportunity to research the situation or experience in-depth to gather information.

The FAST program was designed to help the researchers view and understand the change in relationship behavior dynamics of a mother and child from the aspect of communication capacity within the scope of family and community. The case study allows the researcher to access and develop relevant information to explain the findings holistically and clearly (Creswell \& Clark, 2017). Additionally, Burns (1995) emphasizes that the application of this approach encourages the participation of respondents who possess similar characteristics based on their background, events, culture, social values, and environment.

Participants and procedures

In this study, the researchers employ the purposive sampling technique that is criterion-based (Silverman, 2000). The criteria set for the respondent is that the mother has to be registered with Persatuan Ibu Tunggal Rangkaian Hati (PITRAH) and receive aid from the Welfare Department Malaysia (JKM). Table 1 shows the demographics of mother respondents of the FAST Program. 
Table 1: Demographic Characteristics of Respondents (Mother)

The FAST teenagers who were involved in the research interview were three adolescent boys

\begin{tabular}{|c|c|c|c|c|c|c|c|}
\hline No & Mother & Age & Status & Occupation & Education & $\begin{array}{c}\text { No. of } \\
\text { childre } \\
n\end{array}$ & $\begin{array}{c}\text { Attendance } \\
\text { in FAST } \\
\text { program }\end{array}$ \\
\hline 1 & IBUF1 & $\begin{array}{l}\text { The } \\
50 \text { s }\end{array}$ & $\begin{array}{c}\text { A single } \\
\text { mother } \\
\text { (widowed) }\end{array}$ & $\begin{array}{c}\text { Local cakes } \\
\text { Seller }\end{array}$ & $\begin{array}{l}\text { Complete } \\
\text { d primary } \\
\text { education }\end{array}$ & 2 & $100 \%$ \\
\hline 2 & IBUF2 & $\begin{array}{l}\text { The } \\
\text { late } \\
30 s\end{array}$ & $\begin{array}{l}\text { A single } \\
\text { mother } \\
\text { (divorced) }\end{array}$ & $\begin{array}{l}\text { Factory } \\
\text { worker }\end{array}$ & $\begin{array}{c}\text { Complete } \\
d \\
\text { secondary } \\
\text { education } \\
\text { (SPM) }\end{array}$ & 2 & $70 \%$ \\
\hline 3 & IBUF3 & $50 \mathrm{~s}$ & $\begin{array}{c}\text { Single } \\
\text { mother } \\
\text { (widowed) }\end{array}$ & $\begin{array}{c}\text { Local cakes } \\
\text { Seller }\end{array}$ & $\begin{array}{l}\text { Secondary } \\
\text { (did not } \\
\text { complete) }\end{array}$ & 3 & $100 \%$ \\
\hline
\end{tabular}

who were referred by their schools because of their disciplinary problems and misconduct. Table 2 shows the demographics of the adolescent respondents of the FAST program.

Table 2: Demographic Characteristics of Respondents (Teenager)

\begin{tabular}{|c|c|c|c|c|c|}
\hline $\begin{array}{l}\mathbf{N} \\
\mathbf{O}\end{array}$ & $\begin{array}{l}\text { Adoles } \\
\text { cent }\end{array}$ & $\begin{array}{l}\text { Gende } \\
r\end{array}$ & $\begin{array}{l}\text { Problem of } \\
\text { Misconduct }\end{array}$ & $\begin{array}{l}\text { Attendance to } \\
\text { school }\end{array}$ & $\begin{array}{l}\text { Attendance } \\
\text { at the FAST } \\
\text { program }\end{array}$ \\
\hline 1 & $\begin{array}{l}\text { FASTr1 } \\
\text { SMK } \\
\text { Jalan } \\
\text { Tiga }\end{array}$ & Male & $\begin{array}{l}\text { Truant, low academic } \\
\text { achievement }\end{array}$ & $\begin{array}{l}\text { Frequency of } \\
\text { truancy } \\
5 \text { times a month }\end{array}$ & $100 \%$ \\
\hline 2 & $\begin{array}{l}\text { FASTr2 } \\
\text { SMK } \\
\text { Jalan } \\
\text { Tiga }\end{array}$ & Male & $\begin{array}{l}\text { Truant, low academic } \\
\text { achievement } \\
\text { Identity confusion }\end{array}$ & $\begin{array}{l}\text { Frequency of } \\
\text { truancy } \\
\text { More than } 5 \text { times a } \\
\text { month }\end{array}$ & $100 \%$ \\
\hline 3 & $\begin{array}{l}\text { FASTr3 } \\
\text { SMK } \\
\text { Jalan } \\
\text { Tiga }\end{array}$ & Male & $\begin{array}{l}\text { Truant } \\
\text { Smoking } \\
\text { Low academic } \\
\text { achievement }\end{array}$ & $\begin{array}{l}\text { Consistently absent } \\
\text { / 1-3 times a week }\end{array}$ & $100 \%$ \\
\hline
\end{tabular}

The study also involves four informants who are in the implementation group and are directly and indirectly involved as part of the FAST program community circle; namely a counselor, class teacher, a parent-teacher association (PIBG) representative, and a senior assistant of student affairs. These informants' task is to contribute input on the significant impact of the FAST program. This program involves three phases; specifically Phase 1 (Preliminary); Phase 2 Program Implementation and Phase 3 (Post-program implementation) which were completed within 8 months ( 32 weeks). 
Research data is collected using in-depth interview sessions, observations, and analysis of literature (Creswell \& Creswell, 2017). The study involves the triangulation process based on the data collection techniques used (Merriam, 1998). The interview data provides an insight into the respondents' self-reflections which describe their feelings, trust issues, and selfanxiety (Miller \& Glassner, 1997). Besides that, it also develops a rapport between the researcher and the respondents of the study (Yin, 2009). This study takes into account naturalistic observations that enable the researchers to scrutinize the respondents' behaviors (Noah, 2002). The researchers are also able to observe, listen and experience the real atmosphere during the 8-week FAST program and the changes that have occurred after completing the FAST program. Additionally, the researchers document all the activities of the respondents and the comments they make as a form of reflective findings that come in the shape of speculations, feelings, problems, ideas, and prejudices (Bogdan \& Biklen, 2003). The analysis of literature serves as additional sources of reference of text content and additional evidences (Yin, 2009).

\section{Data Analysis}

The process of data analysis involves numerous levels which include transcribing, data organization, habituation (familiarisation with data), coding, the establishment of theme, demonstration of trust and validity, and reporting. All the interview data undergo the coding and categorization process to arrive at relevant themes. The data is then analyzed manually and by using the Nvivo8 software.

\section{Results and Discussions}

The findings are presented to identify the strength and weaknesses of FAST as an intervention program in the Malaysian context where the implementation of activities are concerned which are based on FAST's 3-level planned implementation phase. Table 3 illustrates the effectiveness of the FAST program to be applied in family institutions and school and community collaborative networks based on themes acquired through data collection.

\section{i. $\quad$ Phase 1: Preliminary (Before implementation of the program)}

It was found that at Phase 1 (preliminary) when the program was not yet implemented, provision of resources such as funding, human resource for training, and program expenses have been carried out in a systematic and organized manner. Program needs in the area of expenses were recorded from the beginning and discussed in detail with capital holders to ensure the success of the program as thus stated "I was fully involved from the beginning of the program and saw through the systematic implementation of the FAST program"

It was also at this phase that facilitators who are skilled in conducting FAST program activities were selected. Training is seen as crucial to parents and teenagers groups, the administrative group that is made up of counselors, class teachers, and school administrators. Facilitators are responsible to ensure that the success of the FAST program is relevant to all. "...we help in the provision of space, a representative for parents through PIBG and students with excellent academic records and personalities to serve as exemplary teenagers...". In addition to that, early exposure through briefings is crucial to ensure that the respondents understand the objectives and aims of the program implementation. "...this is a new program and this is the first time I am involved in such a program. The early exposure through the workshop 
organized for facilitators is crucial and organizers were able to organize it well...the trainer was from the international FAST team and was supervised by professionals from UPM..."

\section{ii. $\quad$ Phase 2: During Program Implementation}

Next was Phase 2, where the program targeted family and adolescent groups. To explore the relationship dynamics between mothers and children, the FAST respondents selected three activities that were expected to impact family table activities, peer activities, and one to one activity as stated in Table 3:-

Table 3: The FAST program's planned activities

\section{Fast Activities}

\section{Description of Activities}

1. The family unit and family table (45 minutes)

2. Peer Group Time (45 minutes)

3. One-to-One Time ( 30 minutes)

4. Game and Lotto (15 minutes)

5. Closing circle (15 minutes)
- Eating activity with family unit

- Joint activity with the family unit.

- Discussion between adult participants

- Discussion between adolescent participants

- The quality face-to-face program between mother and adolescent

- Reflection

- Each family takes a turn to win a lucky basket

- The lucky basket is unique because it contains gifts for every member of the family

- Announcement and handing of contributions for the coming week's food preparation session

a. Family Table: eating together

The participants reported that the family table practice helped strengthen family ties because such activities were not commonly conducted before the FAST program:-

"...before this, we rarely eat together due to unfamiliarity. "Em...rarely...not sure, used to eating by myself. If relatives come visiting, mother would arrange for feasts, so I will join in... during Raya...."

Most teenagers prefer eating by themselves because it is faster that way.

...if the mother asks to have breakfast together, I will be sleeping...during lunch after returning from school, I would eat alone...it's the same for dinner, it's difficult to eat together in a group if in a rush...

The planned activities and research findings recorded during the entire duration of the FAST program found that the activity of eating together with the family was capable of changing the habits of the teenagers (Fearnow-Kenney et al., 2016; Turley et al., 2017). It also allowed 
mothers to guide children on proper eating manners while eating at the table and this appeared to appeal to the teenagers to spend more time together during their meals. The teenagers were found to spend more time sharing their stories or discussing family-related matters or problems. Zakri and Saemah (2015) also proved the influence of peers on negative behavior, but it was found that participation in the FAST program which inculcated positive behavior through sound role models and positive elements could improve the relationship between the adolescent and mother (Fearnow-Kenney et al., 2016).

\section{b. Joint family activities with peers}

Findings revealed that initially, the teenagers felt awkward and were afraid to share their stories with other family members. However, as the activities progressed, all the families involved were able to feel at ease to complete the activities. Discussions of participants were open and even involved the admission of mistakes made: -

"There are a lot of things...I did not do it...but the teacher said I did because I joined my friends." According to the participant, the blame was accepted because he did not want to end up losing his friends. But when the demerit points began increasing, the teacher contacted his mother. "Mother was angry, she did not want me to continue my friendship... because she was fed-up that I was playing truant."

The role of mothers was further strengthened and expanded through participation in joint activities such as football competitions, with adolescent children. The sense of togetherness found through such activities was found to bring about changes in the teenagers' intelligence to act more mature, especially when making choices. The changes seen in mothers who, in the past, were always quick to dismiss the outpourings of their children as trivial, were seen as motivational encouragement for the teenagers to become close with their mothers once again and pay heed to the advice given:

"..I realize that I was not being fair, emm there were a lot of issues concerning him that I disregarded. But the one-to-one session helped. After the fifth week, each time after he completes the program, I would ask him... what was discussed... what did he talk about...em we began having similar sessions at home..."

"..initially I felt very awkward...Mother was fierce, I was afraid she did not want to join this program... at the beginning, I did not talk much to mother, but after that, we became better..."

To further strengthen the relationship between mother and child, the FAST program introduced the time together element in the one-to-one activity as the highlight of the program. This weekly activity involves a discussion between mother and child to choose a topic of choice for the sharing session with peers. According to Ghani et al. (2014) and Najwa et al. (2019), the quality time together shapes healthy emotions and enables the child to feel loved by the parents besides getting to know the mother better. Frequent time together spent with families can help control deviant behaviors.

Involvement of teenagers in acts of misconduct often results in disrupted communication, increased pressure, lack of attention, retaliation, and environmental pressure (Saleh \& Said, 
2015). As such, the research findings through the FAST program focus on the positioning of mothers as leaders of families to guide their adolescent children towards embracing positive behavior in order for them to become more confident, avoid disciplinary problems such as breaking rules and stop playing truant (Turley et al., 2017).

\section{iii. $\quad$ Phase 3 (After the implementation of the program)}

Findings in Phase 3 after the implementation of the FAST program can be divided into 2; shortterm and long-term effects. The targeted FAST program showed positive reactions after joining and participating in the activities. Before participating in the FAST program, mothers and teenagers were found to frequently argue and misunderstand each other. This was found to have greatly perturbed the mothers especially when the children protested when advised or reprimanded in matters relating to disciplinary problems:

"...l can't even point out anything, can't say that he is wrong. He will then start to retaliate. Won't talk, throws things around..or fight with his siblings...it makes me angry. Should I hit him?.. I won't be able to, he is bigger than me..."

However, upon participating in the FAST program and the various planned activities shown in Table 3, it was found that the relationship between the mother and adolescent child had greatly improved their daily life.

"....there are changes (while nodding). Anger can be controlled... if I feel extremely angry, I take ablution... before this, I knew, but I never did it. In the FAST program, the facilitator constantly reminded to do this... alhamdulillah"

The disciplinary problems began reducing and a positive change in behavior was seen in communication:-

"...it looks like it's reduced (smoking) because I rarely go out. Stop? I can't say anything now because I am too used to smoking... maybe...could happen..."

Long-term results have shown progress in the teenagers in the aspects of their behavior at school, home, and to their academic achievement. Findings also saw elements of sustainability of positive impacts of the FAST program in all family members involved. To monitor the long-term results, FAST has established a fast work team that is responsible for making home and school visits a month after the participants graduate from the FAST program for 3 consecutive months. Through the fast work team, the researchers will attempt to build interactions with the teenagers and mothers despite the completion of the program. It was found from observations that the expectation of changing the negative attitudes into positive outcomes was met.

"...alhamdulillah, after they participated in FAST I have not received any complaint from the disciplinary teacher about their attitude. The feedback from parents too has been good..."

Findings revealed that the collaboration between all parties was optimistic as a result of the change in attitude and behavior of the teenagers "... believe that if we give them space and 
opportunities they can succeed. Perhaps not excellent but succeed...because they all have potential." 3 months after the implementation of the program, follow-up interviews confirmed that the respondents reported that many healthy practices were adopted from the FAST program. "...I still remember...it feels recent. The program is good, my son spends more time at home. He does not go out much..haa.. That's good, we have time to chat, he likes to tell me stories about his life, and I would listen. He also fights less with his sibling..."

The participants are also found to now spend more quality time eating together, do things together, listen more to the teenagers and give them importance in family discussions.

"he (the adolescent) goes out less...only sometimes. He goes out in the evenings, plays football nearby. After returning from school, he just rests. Since he now has his room, he does not creep out of the house much.."

On the whole, the research findings report that the essence of the activities planned for the FAST program is the idea that interactive togetherness is highly effective in influencing the formation of a mother and child relationship (Chapman, 2003).

\section{Conclusion}

Briefly, this study aimed to explore the strengths and weaknesses of the FAST program as a form of intervention in mother and adolescent relationships in a familial institution. The recurring themes point to the fact that the FAST program has great potential to be adopted into the nation's familial and educational institutions. The research findings also showed that the program plays an important role in improving mother-adolescent relations which can encourage a collaborative network in the community. The activities covered in the FAST program model are carried out in 3 phases over 8 weeks which include Phase 1 (Preliminary); Phase 2 Program Implementation and Phase 3 (Post-program implementation); and are aimed at improving and strengthening the relationship of mothers and teenagers on a short term and long basis. The change in attitude and behavior of teenagers after the planned activities of the FAST program has resulted in improved communication and relationship with their mothers and also at the school level. On the whole, the FAST program has strengthened the relationship dynamics of the mother and child and enabled a new dimension in the understanding of the self of both mothers and teenagers, besides creating possibilities of quality time together; and this dynamic shift is seen as relevant to be implemented in Malaysia in time to come.

\section{References}

Abdullah, F., Ismail, K., \& Omar, M. (2015). Sharing intervention models of smart schoolsfamilies in child education. The Malaysian Journal of Social Administration, 11(1), 6585.

Akhtar, S., Awan, S. H., Ismail, K., \& Naveed, S. (2017). Social capital and learning organisation: Is it worth to engage in networking? International Journal of Learning and Change, 9(3), 208-227. https://doi.org/10.1504/IJLC.2017.086853

Amin, L. H. M., Hafiz, M. R. A., Kamarulzalis, M. N. A., Ibrahim, A. H., Taib, N. M., Ramlan, N. H., \& Husin, M. R. (2019). Issues of confusion in behaviour: School truancy issues. International Journal of Humanities, Management and Social Science, 2(1), 51-64. 
Awal, N. M., Jaafar, M. F., Azlan, M., \& Lateh, H. (2014). Maintenance of mother tongue: Patterns of language choice at the malaysian-thai border. Procedia - Social and Behavioral Sciences, 118, 282-287.

Bakar, A. A. (2015). Family communication and conflict management: From the perspective of Malay teenagers. Jurnal Pengajian Media Malaysia, 17(1), 11-28.

Bandura, A. (1977). Social Learning Theory. Prentice.

Barnes, H. L., \& Olson, D. H. (1985). Parent-adolescent communication and the circumplex model. Child Development, 56(2), 438-447.

Baumrind, D. (1989). Rearing competent children. Jossey Bass.

Baxter, P., \& Jack, S. (2008). Qualitative case study methodology: Study design and implementation for novice researchers. The Qualitative Report, 13(4), 544-559.

Becker, B. E., \& Luthar, S. S. (2002). Social-emotional factors affecting achievement outcomes among disadvantaged students: Closing the achievement gap. Educational Psychologist, 37(4), 197-214.

Berger, N., Ellmers, T., Oyefeso, A., Thomas, B., \& Clancy, C. (2016). Families and Schools Together (FAST) (UK 2014; Aggregate Evaluation Report).

Bezrukova, O., \& Samoylova, V. (2015). The authoritarian syndrome in attitudes and educational practices of Russian parents. Procedia-Social and Behavioral Sciences, 165, 234-240.

Bogdan, R. C., \& Biklen, S. K. (2003). Qualitative research for education. Allyn \& Bacon.

Brody, L. R. (1985). Gender differences in emotional development: A review of theories and research. Journal of Personality, 53(2), 102-149.

Burns, R. B. (1995). Introduction to Research Methods (2nd ed.). Australia.

Chapman, E. (2003). Alternative approaches to assessing student engagement rates. Practical Assessment, Research \& Evaluation, 8(13), 1-10.

Clarke, A. M., Morreale, S., Field, C.-A., Hussein, Y., \& Barry, M. M. (2015). What works in enhancing social and emotional skills development during childhood and adolescence. WHO Collaborating Centre for Health Promotion Research.

Creswell, J. W., \& Clark, V. L. P. (2017). Designing and conducting mixed methods research (3rd ed.). Sage publications.

Creswell, J. W., \& Creswell, J. D. (2017). Research design: Qualitative, quantitative, and mixed methods approaches. Sage publications.

Desa, A., Yusoof, F., Zamani, Z. A., Kadir, N. B. A., \& Sani, M. N. M. (2015). Parenting skills, functions of families and psychological well-being among parents. Jurnal Psikologi Malaysia, 29(2), 32-42.

Fearnow-Kenney, M., Hill, P., \& Gore, N. (2016). Child and parent voices on a communitybased prevention program (FAST). School Community Journal, 26(1), 223-238.

Foxcroft, D. R., Callen, H., Davies, E. L., \& Okulicz-Kozaryn, K. (2017). Effectiveness of the strengthening families programme 10-14 in Poland: Cluster randomized controlled trial. European Journal of Public Health, 27(3), 494-500.

Garstin, L. H. (1948). The school as an integrating agency in community life. The Journal of Educational Sociology, 21(7), 409-416.

Ghani, M. F. A., Radzi, N. M., Ghavifekr, S., Kenayatullah, H. B., \& Muhamad, M. (2014). pengurusan disiplin murid di sekolah kawasan bandar dan luar bandar: Perspektif pemimpin sekolah [Discipline management of students in urban and rural schools: perspectives of a school leader]. JuPiDi: Jurnal Kepimpinan Pendidikan, 1(1), 7-40. 
Grayson, H. (2013). Rapid review of parental engagement and narrowing the gap in attainment for disadvantaged children. Slough and Oxford: National Foundation for Educational Research.

Gross, J. (2015). Strong school-community partnerships in inclusive schools are" part of the fabric of the school... We count on them". School Community Journal, 25(2), 9-34.

Harrell, A. W., Mercer, S. H., \& DeRosier, M. E. (2009). Improving the social-behavioral adjustment of adolescents: The effectiveness of a social skills group intervention. Journal of Child and Family Studies, 18(4), 378-387.

Hashim, R., \& Nin, R. M. (2011). Students Breaking School Discipline: The connection between family interaction and self-concept. Jurnal Kemanusiaan, 18, 14-30.

Hidayah, N., \& Suhaizal, J. D. (2018). The role of sociology in environmental education: A challenge. Online Journal for TVET Practitioners, 3(1), 23-45.

Ishak, D., Selvaratnam, D. P., \& Idris, N. A. (2009). Issues and challenged of single mothers in facing global environmental changes. Prosiding Perkem IV, 1, 324-336.

Kratochwill, T. R., McDonald, L., Levin, J. R., Scalia, P. A., \& Coover, G. (2009). Families and schools together: An experimental study of multi-family support groups for children at risk. Journal of School Psychology, 47(4), 245-265.

Manap, J., Baba, M., \& Rahman, N. S. A. (2013). Parental communication approach in mothers' families. Jurnal of Human Development and Communication, 2, 73-87.

McDonald, L., \& Frey, H. E. (1999). Families and Schools Together: Building Relationships. Juvenile Justice Bulletin. (NCJ-173423). Department of Justice,.

Merriam, S. B. (1998). Qualitative Research and Case Study Applications in Education. JosseyBass Inc.

Miller, J., \& Glassner, B. (1997). The 'inside' and the 'outside': Finding realities in interviews. In D. Silverman (Ed.), Qualitative research: Theory, method and practice (pp. 99-112). Sage.

Najwa, N., Ashaari, S. H., Sumadi, S. N., Salleh, N. A., Ismail, N. I., Adenan, N. A. H., \& Husin, M. R. (2019). Problems of unrestricted interaction among teenagers in schools. International Journal of Humanities, Management and Social Science, 2(1), 38-50.

Noah, S. M. (2002). Research design: Philosophy, theory and practice. Penerbit UPM.

Nurshahizan, N. (2014). Parenting style towards academic achievements of secondary school students [Master Thesis]. Universiti Tun Hussein Onn.

Othman, M., Sarnon, N., \& Zakaria, E. (2019). Exploring the functionality of families of uncontrollable female teenagers referred to by parents for social work intervention. $E$ Bangi, 16(9), 1-19.

Patton, B. R., \& Giffin, K. (1977). Interpersonal communication in action: Basic text and readings. Harper \& Row.

Patton, M. Q. (2002). Two decades of developments in qualitative inquiry: A personal, experiential perspective. Qualitative Social Work, 1(3), 261-283.

Saleh, F., \& Said, Z. A. (2015). Factors and roles of family institutions in preventing misconduct and deviance among teenagers. Proceeding: 7th International Seminar on Regional Education, 1, 147-157.

Sanders, M. G., \& Harvey, A. (2002). Beyond the school walls: A case study of principal leadership for school-community collaboration. Teachers College Record, 104(7), 13451368.

Sarnon, N., Saim, N. J., Ibrahim, F., Hoesni, S. M., Nen, S., Subhi, N., Mohamad, M. S., Alavi, K., \& Tsuey, C. S. (2018). Exploring roles of uncontrollable teenagers on family issues: 
Towards understanding self-discovery of teenagers from dysfunctional families. Jurnal Psikologi Malaysia, 32(4), 34-50.

Sheldon, S. B. (2016). Moving beyond monitoring: A district leadership approach to school, family, and community partnerships. In S. B. Sheldon \& E. M. Kim (Eds.), Family-school partnerships in context (pp. 45-63). Springer.

Talib, J., Mamat, M., \& Ibrahim, M. (2017). Exploration of parenting style among parents of low social class with underachieving children. Jurnal Psikologi Dan Kesihatan Sosial, 1, 8-12.

Taylor, C. J. (2015). Gendered pathways to recidivism: Differential effects of family support by gender. Women \& Criminal Justice, 25(3), 169-183.

Trees, A. R. (1999). Nonverbal communication and the support process: Sensitivity and support seeking in interactions between mothers and young adult children [PhD Thesis]. University of Washington.

Turley, R. N. L., Gamoran, A., McCarty, A. T., \& Fish, R. (2017). Reducing children's behavior problems through social capital: A causal assessment. Social Science Research, 61, 206217.

Valentine, J. C., Leach, S. M., Fowler, A. P., Stojda, D. K., \& Macdonald, G. (2019). Families and Schools Together (FAST) for improving outcomes for children and their families (No. CD012760; pp. 1-92). Cochrane.

Voydanoff, P., Donnelly, B. W., \& Fine, M. A. (1988). Economic distress, social integration, and family satisfaction. Journal of Family Issues, 9(4), 545-563.

Yahaya, M., \& Yatim, A. D. A. (2018). Impact of religious practices on delinquent students through the spiritual model on personality empowerment (mospes). Jurnal Penyelidikan Dedikasi Jilid, 14(8), 32-50.

Yin, R. K. (2009). Case study research: Design and methods (4th ed.). Sage.

Yousef, D. A. (2017). Organizational commitment, job satisfaction and attitudes toward organizational change: A study in the local government. International Journal of Public Administration, 40(1), 77-88.

Zakri, M., \& Saemah, M. (2015). Meta-conduct skills and decision-making skills among students with and without disciplinary problems. Jurnal Pendidikan Malaysia, 40(2), 175-183.

Zulkefli, N., \& Mustapha, Z. (2016). Teenagers with divorced parents in Malaysia: A scrutiny of emotional expressions. Malaysian Journal of Society \& Space, 12(9), 150-160. 